\title{
WESS: an interdisciplinary approach to catchment research
}

\author{
Olaf Kolditz • Hermann Rügner • Peter Grathwohl • \\ Peter Dietrich · Thilo Streck
}

Received: 22 March 2013/ Accepted: 29 March 2013/Published online: 10 April 2013

(C) Springer-Verlag Berlin Heidelberg 2013

Predicting how environmental change (climate, land use, etc.) will affect hydrological response and water quality on the long term is a grand challenge in Environmental Earth Sciences. It requires fundamental understanding of functioning of catchments and landscapes:

- How do they process pollutants on the large scale (natural attenuation of diffuse pollution)?

- How are processes such as flow, transport and reaction coupled?

- What is the role of interfaces (atmosphere-plants-soilgroundwater-surface waters)?

- How can we monitor and model water and solute fluxes across the different scales involved?

To meet these challenges, a number of novel research programs and networks focusing on entire catchments or landscapes have recently been established such as CUASHI

Editorial to the EES Topical Issue "Catchment Research".

O. Kolditz · H. Rügner · P. Grathwohl · P. Dietrich · T. Streck Water and Earth System Science (WESS) Competence Cluster, 72074 Tübingen, Germany

O. Kolditz $(\bowtie) \cdot$ P. Dietrich

Helmholtz Centre for Environmental Research, UFZ,

04318 Leipzig, Germany

e-mail: olaf.kolditz@ufz.de

O. Kolditz

Technische Universität Dresden, 01062 Dresden, Germany

P. Grathwohl · P. Dietrich

Eberhard Karls University of Tübingen,

72074 Tübingen, Germany

T. Streck

Universität Hohenheim, 70593 Stuttgart, Germany
(Toran and Hooper 2004) or TERENO (Zacharias et al. 2011). "Catchment Research" is the second Topical Issue (TI) in Environmental Earth Sciences with a focus on international hydrological research. Most of the material has been provided by the Water Earth System Science Competence Cluster (WESS) founded by the Universities of Tübingen, Stuttgart, and Hohenheim together with the Helmholtz Centre for Environmental Research, UFZ (Grathwohl et al. 2013). The TI "Catchment Research" is a follow-up of the IWAS issue (Kalbus et al. 2012) which was dealing with Integrated Water Resources Management in different climate-hydrological sensitive areas in the world.

"Catchment Research" is organized in three sections, starting with results from the initial period of the WESS project, followed by invited studies from catchment research in Europe, Asia and South America. The last part of the volume presents overview and technical papers on the development of terrestrial observatories, in particular, the TERENO network. A "News and Views" contribution concerning the networking and community efforts of the Water Science Alliance initiative is provided at the end of this issue (Krueger and Teutsch 2013).

The first section of "Catchment Research" consists of contributions from the Water Earth System Science Competence Cluster. Grathwohl et al. (2013) provide a comprehensive overview of the WESS research concept and field sites. Studies presented put emphasis on experimental investigations in various sub-catchments of the Neckar River basin, e.g., using fluorometry (Lemke et al. 2013), assessing hyporheic exchange processes (Osenbrück et al. 2013), and delineating subsurface heterogeneity underneath the river bed (Doro et al. 2013). David et al. (2013) are investigating the influence of sewer overflows to accumulation patterns in river bed sediments. The second 
section deals with hydrological characterization and modelling of surface and subsurface systems including travel time analysis and more complex reactive transport processes at the hillslope scale (Woehling et al. 2013; Selle et al. 2013; Maier et al. 2013). Schwientek et al. (2013) and Ruegner et al. (2013) look at the nitrate cycle in an agricultural area and the water quality in rivers related to urban and agricultural pressure. Pause et al. (2013) present the results of a multi-sensor campaign (with airborne and field experimental data) to characterize the shallow subsurface. Gayler et al. (2013) assess the relevance of processes in crops and the subsurface for evapotranspiration, i.e. processes at the interface to the atmosphere. Delfs et al. (2013) present a new concept for coupling process based surface/ subsurface flow models including dynamic flow processes in the unsaturated zone.

The second part of "Catchment Research" assembles a number of hydrological studies from Asia (Middle East, Saudi Arabia), South America (Brazil) and Europe (Austria, Switzerland). Engelhardt et al. (2013a) present a palaeo-groundwater model of the Arabian Peninsula for assessing the groundwater recharge during more humid periods in the Pleistocene as well as Mid Holocene and continuous depletion of the groundwater resources during the Late Holocene. A second modelling approach has been applied for the estimation of groundwater recharge in more recent times (Engelhardt et al. 2013b). Two further studies are dedicated to the Zarqa River catchment and Western Dead Sea Escarpment, two areas on the opposite sides of the Jordan River to improve the understanding of surface runoff and related groundwater recharge mechanisms in semi-arid areas (Schulz et al. 2013; Gräbe et al. 2013; Mallast et al. 2013). Diniz Gonçalves et al. (2013) present a groundwater model of the Pipiripau watershed, a Federal District of Brazil with extreme population growth and related increase of water demand. Several hydrological studies from Austria and Switzerland are described in the second part of the international section with emphasis on Alpine catchments as a contrast to the semi-arid regions beforehand. Altdorff et al. (2013) and Huggenberger et al. (2013) deal with hydrogeophysical methods for non-invasive measurements and the description of aquifer-surface water interaction in typical subalpine river systems in Switzerland. Finally, two contrasting catchment studies from Austria are presented by Klammler et al. (2013), and Strasser et al. (2013) investigating a mountainous catchment in Upper Styria and a basin used for both drinking water supply from groundwater as well as for agricultural leading to nitrate leaching.

The final part of "Catchment Research" contains several overviews and some more technically oriented pieces of work. Richter et al. (2013) report on lessons learnt and future perspectives concerning Integrated Water Resources
Management and the implementation of the EU-Water Framework Directive in Germany. An overview provided by Ghasemizadeh and Schirmer (2013) deals with subsurface flow contributions to the hydrological cycle. Rinke et al. (2013) developed a comprehensive online monitoring system at Rappbode reservoir within the TERENO Bode observatory, the largest drinking water reservoir in Germany. The Berchtesgaden National Park (Bavaria, Germany) as a platform for interdisciplinary catchment research in an alpine region is presented by Marke et al. (2013), investigating trade-offs between the natural resources in the park area and socio-economy. Elmer et al. (2013) demonstrate the application of a similar methodology with focus on ecosystem dynamics in an artificial catchment in Lusatia (Germany). TEODOOR is the data portal of TERENO (Kunkel et al. 2013) and offered as a gate to terrestrial data access from different observatories. Finally, Rink et al. (2013) present a framework for exploration, integration, validation and visualization of comprehensive terrestrial data sets. Data integration (Rink et al. 2012) and simulation platform development (Kalbacher et al. 2012) as well as the subsequent establishment of continuous work flows (Kolditz et al. 2012)—as described in previous issues—are important ingredients for interdisciplinary research and community building in Environmental Earth Sciences as documented in the present "Catchment Research" Topical Issue (Grathwohl et al. 2013).

\section{References}

Altdorff D, Epting J, Van der Kruk J, Dietrich P, Huggenberger P (2013) Delineation of fluvial sediment architecture of subalpine riverine systems using non-invasive hydrogeophysical methods. Environ Earth Sci 69(2). doi:10.1007/s12665-013-2304-4

David T, Borchardt D, von Tümpling W, Krebs P (2013) Combined sewer overflows and their contribution to fine sediment accumulation and the element patterns of river bed sediments: a quantitative study based on mixing models of composite fingerprints. Environ Earth Sci 69(2). doi:10.1007/s12665-013-2447-3

Delfs J-O, Wang W, Kalbacher T, Singh AK, Kolditz O (2013) A coupled surface/subsurface flow model accounting for air entrapment and air pressure counterflow. Environ Earth Sci 69(2). doi:10.1007/s12665-013-2420-1

Diniz Gonçalves T, Gräbe A, Fischer T, Kolditz O, Weiss H (2013) Groundwater flow model of the Pipiripau Watershed, Federal District of Brazil. Environ Earth Sci 69(2). doi:10.1007/s12665013-2400-5

Doro KO, Leven C, Cirpka OA (2013) Delineating subsurface heterogeneity at a loop of River Steinlach using geophysical and hydrogeological methods. Environ Earth Sci 69(2). doi:10.1007/ s12665-013-2316-0

Elmer M, Gerwin W, Schaaf W, Zaplata MK, Hohberg K, Nenov R, Bens O, Hüttl RF (2013) Dynamics of initial ecosystem development at the artificial catchment Chicken Creek, Lusatia, Germany. Environ Earth Sci 69(2). doi:10.1007/s12665-0132330-2 
Engelhardt I, Rausch R, Keim B, Al-Saud M, Schüth C (2013) Surface and subsurface conceptual model of an arid environment with respect to mid and late holocene climate changes. Environ Earth Sci 69(2). doi:10.1007/s12665-013-2303-5

Engelhardt I, Rausch R, Lang U, Al-Saud M, Schüth C (2013) Impact of shifts in climate during the mid- and late holocene on groundwater resources on the Arabian Peninsula. Environ Earth Sci 69(2). doi:10.1007/s12665-013-2362-7

Gayler S, Ingwersen J, Priesack E, Wöhling T, Wulfmeyer V, Streck $\mathrm{T}$ (2013) Assessing the relevance of subsurface processes for the simulation of evapotranspiration and soil moisture dynamics with CLM3.5: comparison with field data and crop model simulations. Environ Earth Sci 69(2). doi:10.1007/s12665-013$2309-\mathrm{z}$

Ghasemizadeh M, Schirmer M (2013) Subsurface flow contribution in the hydrological cycle: Lessons learned and challenges ahead-a review. Environ Earth Sci 69(2). doi:10.1007/s12665-013-2329-8

Gräbe A, Rödiger T, Rink K, Fischer T, Sun F, Wang W, Siebert C, Kolditz O (2013) Numerical analysis of the groundwater regime in the western Dead Sea escarpment, Israel + West Bank. Environ Earth Sci 69(2). doi:10.1007/s12665-012-1795-8

Grathwohl P, Ruegner H, Wöhling T et al (2013) Catchments as reactors: a comprehensive approach for water fluxes and solute turn-over. Environ Earth Sci 69(2). doi:10.1007/s12665-013-2281-7

Huggenberger P, Epting J, Scheidler S (2013) Concepts for the sustainable management of multi-scale flow systems: the groundwater system within the Laufen Basin, Switzerland. Environ Earth Sci 69(2). doi:10.1007/s12665-013-2308-0

Kalbacher T, Delfs JO, Shao H, Wang W, Walther M, Samaniego L, Schneider C, Musolff A, Centler F, Sun F, Hildebrandt A, Liedl R, Borchardt D, Krebs P, Kolditz O (2012) The IWAS-ToolBox: software coupling for an integrated water resources management. Environ Earth Sci 65(5):1367-1380. doi:10.1007/s12665011-1270-y

Kalbus E, Kalbacher T, Kolditz O, Krüger E, Seegert J, Teutsch G, Krebs P, Borchardt D (2012) IWAS-integrated water resources management under different hydrological, climatic and socioeconomic conditions. Environ Earth Sci 65(5):1363-1366. doi: $10.1007 / \mathrm{s} 12665-011$

Klammler G, Kupfersberger H, Rock G, Fank J (2013) Modeling coupled unsaturated and saturated nitrate distribution of the aquifer Westliches Leibnitzer Feld, Austria. Environ Earth Sci 69(2). doi:10.1007/s12665-013-2302-6

Kolditz O, Rink K, Shao HB, Kalbacher T, Zacharias S, Kunkel R, Dietrich P (2012) International viewpoint and news: data and modelling platforms in environmental Earth sciences. Environ Earth Sci 66:1279-1284. doi:10.1007/s12665-012-1661-8

Krueger EH, Teutsch G (2013) International viewpoints and newsThe Water Science Alliance initiative: Germany's researchers join competences to face global water problems. Environ Earth Sci 69(2). doi:10.1007/s12665-013-2280-3

Kunkel R, Sorg J, Eckardt R, Kolditz O, Rink K (2013) TEODOORa distributed geodata infrastructure for terrestrial observation data. Environ Earth Sci 69(2). doi:10.1007/s12665-013-2370-7

Lemke D, Schnegg P-A, Schwientek M, Osenbrück K, Cirpka O A (2013) On-line fluorometry of multiple reactive and conservative tracers in streams. Environ Earth Sci 69(2). doi:10.1007/ s12665-013-2305-3

Maier U, Flegr M, Rügner H, Grathwohl P (2013) Long-term solute transport and geochemical equilibria in seepage water and groundwater in a catchment cross section. Environ Earth Sci 69(2). doi:10.1007/s12665-013-2393-0

Mallast U, Siebert C, Wagner B, Sauter M, Gloaguen R, Geyer S, Merz R (2013) Localisation and temporal variability of groundwater discharge into the Dead Sea using thermal satellite data. Environ Earth Sci 69(2). doi:10.1007/s12665-013-2371-6

Marke T, Strasser U, Kraller G, Warscher M, Kunstmann H, Franz H, Vogel M (2013) The Berchtesgaden National Park (Bavaria, Germany) - a platform for interdisciplinary catchment research. Environ Earth Sci 69(2). doi:10.1007/s12665-013-2317-z

Osenbrück K, Wöhling T, Lemke D, Rohrbach N, Schwientek M, Leven C, Castillo Alvarez C, Taubald H, Cirpka O A (2013) Assessing hyporheic exchange and associated travel times by hydraulic, chemical, and isotopic monitoring at the Steinlach Test Site, Germany. Environ Earth Sci 69(2). doi:10.1007/ s12665-012-2155-4

Pause M, Lausch A, Jagdhuber T, Hejnsek I, Denk A (2013) WESS/ TERENO EnvSens observations 2011: Torward multi-sensor based land surface parameter retrieval at the small catchment scale. Environ Earth Sci (under revision)

Richter S, Völker J, Borchardt D, Mohaupt V (2013) Integrated water resources management and implementation of the EU-Water Framework Directive: lessons learnt and future perspectives from the experience in Germany. Environ Earth Sci 69(2). doi: 10.1007/s12665-013-2399-7

Rink K, Kalbacher T, Kolditz O (2012) Visual data management for hydrological analysis. Environ Earth Sci 65(5):1395-1403. doi: 10.1007/s12665-011-1230-6

Rink K, Fischer T, Selle B, Kolditz O (2013) A data exploration framework for validation and setup of hydrological models. Environ Earth Sci 69(2). doi:10.1007/s12665-012-2030-3

Rinke K, Kuehn B, Bocaniov S, Wendt-Potthoff K, Büttner O, Tittel J, Schultze M, Herzsprung P, Rönicke H, Rink K, Dietze M, Matthes M, Paul L, Friese K (2013) Reservoirs as Sentinels of Catchments: the Rappbode Reservoir Observatory (Harz Mountains, Germany). Environ Earth Sci 69(2). doi:10.1007/s12665013-2464-2

Ruegner H, Schwientek M, Beckingham B, Kuch B, Grathwohl P (2013) Turbidity as a proxy for total suspended solids (TSS) and particle facilitated pollutant transport in catchments. Environ Earth Sci 69(2). doi:10.1007/s12665-013-2307-1

Schulz S, Siebert C, Rödiger T, Al-Raggad MM, Merz R (2013) Application of the water balance model J2000 to estimate groundwater recharge in a semi-arid environment-a case study in the Zarqa River catchment, NW-Jordan. Environ Earth Sci 69(2). doi:10.1007/s12665-013-2342-y

Schwientek M, Osenbrück K, Fleischer M (2013) Investigating hydrological drivers of nitrate export dynamics in two agricultural catchments in Germany using high-frequency data series. Environ Earth Sci 69(2). doi:10.1007/s12665-013-2322-2

Selle B, Rink K, Kolditz O (2013) Recharge and discharge controls on groundwater travel times and flow paths to production wells for the Ammer catchment in south-western Germany. Environ Earth Sci 69(2). doi:10.1007/s12665-013-2281-7

Strasser U, Marke T, Sass O, Birk S, Winkler G (2013) 'Johns Creek Valley' - a mountainous catchment for long-term interdisciplinary human-environment system research in Upper Styria (Austria). Environ Earth Sci 69(2). doi:10.1007/s12665-013-2318-y

Toran L, Hooper R (2004) What's new with CUASHI? Ground Water 42(5):638. doi:10.1111/j.1745-6584.2004.tb02716.x

Woehling T, Samaniego L, Kumar R (2013) Evaluating multiple performance criteria to calibrate the distributed hydrological model of the Upper Neckar Catchment. Environ Earth Sci 69(2). doi:10.1007/s12665-013-2306-2

Zacharias S, Bogena H, Samaniego L et al (2011) A network of terrestrial environmental observatories in Germany. Vadose Zone J 10(3):955-973. doi:10.2136/vzj2010.0139 